\title{
Policies for Widening Participation and Success Factors in Portuguese Higher Education
}

\author{
Susana da Cruz Martins ${ }^{1}$, Helena Carvalho², Patrícia Ávila² ${ }^{2}$, António Firmino da Costa ${ }^{2}$ \\ ${ }^{1}$ Instituto Universitário de Lisboa (ISCTE-IUL), Centro de Investigação e Estudos de Sociologia (CIES-IUL), \& Gulbenkian \\ Professorship, Lisbon, Portugal \\ ${ }^{2}$ Instituto Universitário de Lisboa (ISCTE-IUL), Centro de Investigação e Estudos de Sociologia (CIES-IUL), Lisbon, Portugal \\ Email: susana.martins@iscte.pt
}

How to cite this paper: da Cruz Martins, S., Carvalho, H., Ávila, P., \& da Costa, A. F. (2017). Policies for Widening Participation and Success Factors in Portuguese Higher Education. Creative Education, 8, 210-230. https://doi.org/10.4236/ce.2017.82018

Received: December 30, 2016

Accepted: February 11, 2017

Published: February 14, 2017

Copyright (c) 2017 by authors and Scientific Research Publishing Inc. This work is licensed under the Creative Commons Attribution International License (CC BY 4.0).

http://creativecommons.org/licenses/by/4.0/

(c) (i) Open Access

\begin{abstract}
Portugal's body of higher education students has progressively expanded, and opportunities for graduate certification at this level have multiplied. This paper advances factors that may provide a differentiated explanation of successful paths in higher education. It gives a first-hand account of the recent dynamics of participation in higher education in Portugal within the Bologna Process and uses institutional statistics to compare some of its most relevant characteristics with the European framework as a whole. Secondly, we used an extensive survey of Portuguese higher education students to identify factors potentially involved in successful paths and conducted a multiple logistic binary regression. The resulting model therefore included not only social and educational characteristics and backgrounds but also previous school trajectories, attendance of educational institutions and everyday practices. It identified key factors for success in academic careers by reference to a specific policy context and attendance of higher education. Our definition of these factors (dimensions of analysis) was based on the proposals of Tinto $(2006 ; 1997)$ and Pinto (2002), using the variables available in that survey. Our results point to the relevance of institutional and educational dimensions as differentiated contexts of significance in different academic paths.
\end{abstract}

\section{Keywords}

Higher Education, Students and Graduates, Policies, Portugal, Success

\section{Introduction}

The aim of this article is to contribute to research into the multiplicity of explanatory factors that combine to produce different educational trajectories in academic success. Our analysis is framed by a context of enlargement and policies 
designed to increase the number of students resulting from the implementation of the Bologna Process in Portugal. The main research question is identifying the most important explanatory factors of successful careers in higher education. While some of them have already been widely tested separately, here we feel it is particularly relevant to obtain a model in which these dimensions are part of an explanatory whole.

In this sense, the first part presents some of the recent dynamics involved in participation in Portuguese higher education, and additionally proposes a comparative European framework for some of the most important characteristics. This will be viewed with regard to the very important policy-making contexts that address the higher education system in national and European terms. The second part of this article discusses some of the theoretical and analytical contributions that problematise not only the trend towards an opening up of the system but also the persistence of inequalities in access to and success in higher education. At the end, though of central significance, we present the results of a model directed at explaining the many factors potentially involved in experiencing success in higher education in Portugal. This proposal allows us to operationalise some of the fundamental dimensions encountered in the theoretical models of, for example, Vincent Tinto (2006; 1997) and José Madureira Pinto (2002), who analyse successful educational careers. These contributions are crucial because they allow us to conduct a multidimensional analysis of academic success, considering not only social and educational characteristics at the outset, but also available indicators of these students' academic and social integration experiences.

We developed a model for interpreting success in higher education using logistic regression based on the hierarchy of the different analytical dimensions presented. These dimensions were socio-demographic characteristics (Block 1), social origins (Block 2), previous education (Block 3), training and education institutions in HE (Block 4) and daily life indicators (Block 5). Success in HE was measured on the basis of the students' answer as to whether they have ever failed a year in higher education. Though this indicator contains some conceptual and operational problems, it points to broad measurements, which in themselves provide interesting analytical advantages.

The primary empirical basis for our analysis is the data from a nationwide Survey of the Socio-economic Conditions of Higher Education Students that was carried out throughout the country in 2006 via Portugal's participation in Eurostudent Project $\mathrm{III}^{1}$ ), and involved in particular the sub-sample of Portuguese students in the first cycle of higher education. The indicators used to define predictors of academic success were only included in the Portuguese questionnaire sent out in 2006 (within the Eurostudent Survey).

To complement this data, we use official statistical information from the Gen-

${ }^{1}$ The EUROSTUDENT Project collects and provides comparable European data on the social dimension of European higher education. The main focus is on students' socio-economic backgrounds and living conditions and also on temporary international mobility. The project provides reliable, insightful cross-border comparisons. 
eral Directorate of Statistics of Education and Science (DGEEC/MCE) and Eurostat. This will allow an initial up-to-date and comparative introductory framework for some of the characteristics of the higher education system.

\section{Participation and Graduation in Higher Education: Scenarios and Dynamics}

Since the end of the 1990s, the Bologna Process has been asserting itself from the perspective of a convergence of policies, institutional and course designs, and certification, with a view to the construction of a common European Area for Higher Education (Rauhvargers, Deane, \& Pauwels, 2009). One of the main aims of this process was to enhance the competitiveness and autonomy of higher education institutions and broaden the social base of their students. Indeed, the social dimension was one of its most central aspects and major concerns (Bologna Process Working Group, 2007). This whole process results, in part, from guidelines for the widening (participative equity) and harmonisation of higher education and its institutional, social, and economic dimensions in Europe. "Educational success" also involves the performance of the various national systems and their capacity to respond to pressing qualification needs, that welcome different educational trajectories (continuous or interspersed) and life trajectories represented by men and women of various social origins and by both a young and an adult population (Martins, 2015). Though gradual, this opening up has been progressively more evident in the students' access to, attendance at and certification by the Portuguese higher education system (cf. Martins et al., 2007; Mauritti \& Martins, 2009).

The analysis that follows gives an up-to-date overview of participation in higher education from two perspectives. The first is diachronic and provides a general idea of the population at this level in Portugal (2.1). The second is a brief comparison with the European Union of the importance of certain processes and changes that have occurred in Portugal (2.2).

\subsection{Recent Dynamics in Portugal}

In recent years, higher education has been a focal point of interest, both as an object of study and an object of policy formulation within the framework of present-day societies and the strategic planning for their competitiveness.

At this point, we will also refer to the segments of the student population involved in an increase in access to higher education in Portugal. One of the guarantees of greater openness in the national higher education system concerns the (highly affirmative) presence of women. Their great disadvantage at this point is well known (in the older generations), but recent years have seen this contingent prevail in higher education (Martins et al., 2007; Martins, 2012, 2015). One could even say that in the last 15 years the difference between women and men enrolled in higher education has decreased.

The presence of different age segments also implies a certain progressive expansion in higher education. Though we are primarily dealing with a young 
population-approximately $60 \%$ are less than 23 years older age groups are, however, gaining importance among the student body. In 15 years, there was a $3 \%$ increase in students over 35 years of age, an effect especially noted in recent years (cf. DGEEC/MCE). In fact, today we are witnessing institutional and political dynamics on a global scale in which lifelong learning and ever more highly qualified educational trajectories are promoted. Signs of the expansion and greater flexibility of higher education in Portugal can be seen in policy measures aimed at attracting new target segments. This may be happening for a number of reasons and some of them are relatively new in Portuguese higher education. For instance, some people are moving on to the next level of study. Others are returning after being forced to drop out due to family, education or work situations but are now able to resume their studies in a way more suited to their current life routines.

The implementation of the Bologna Process in Portugal (as of the mid-2000s) encouraged policies aimed at attracting non-traditional students (Martins, 2015). Examples are those that address access for people aged 23+ (Decree-Law No.64/2006) and the part-time student regulations (Decree-Law No.107/2008). These measures fit in with the guidelines on reforms in the Bologna Process. However, even if the process of convergence is taking place in Portugal (as is evident in comparison with other European countries), the fact remains that institutional diversity and organisational specificity are reflected in a higher education system that is fragmented and atomised throughout the country (Pinto, 2002), as we attempt to show below. If it is an impossible task to seek unanimity regarding, for example, the norms and forms of excellence (Perrenoud, 2003) on which educational success depends, then a higher education system with the above characteristics reinforces this difficulty even more.

Portugal was one of the first countries to set up a national qualifications framework that met the Bologna requirements (Rauhvargers, Deane, \& Pauwels, 2009). The Bologna Process seems to have brought possibilities for more flexible, adaptable organizations and courses for different types of student. One of the most immediate effects seems to have been an increase in demand, particularly in state education.

The pairs "university and polytechnic education" and "public and private sector" spring to mind. When they are combined, four distinct types of institutions emerge. A reading of the data in Figure 1 demonstrates the growing importance of the public sector in higher education participation in Portugal (84\% of students). The weakening of private education in the last decade is well known. Private education has declined in relation to public education (a reduction of $13 \%$ of its attendees), the former currently representing $16 \%$ of students in Portuguese higher education. Students enrolled in polytechnics represent a third of those studying in higher education. This relationship between polytechnics and university proportions has remained stable in the last 15 years, but universities have gained some significance when compared to polytechnic education.

With regard to educational fields, the greatest share is assumed by those 


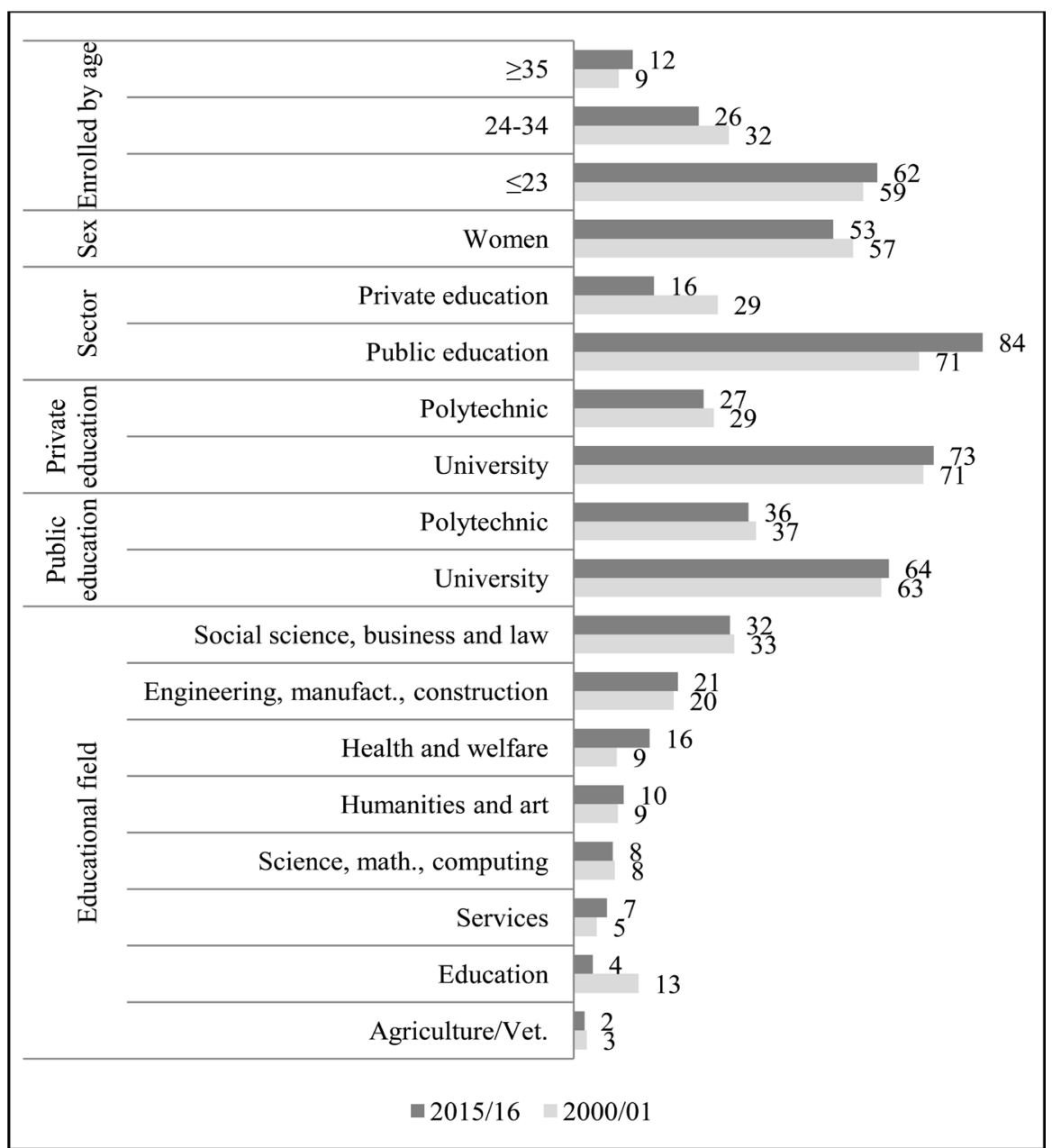

Note: Students by age: 2014/15. Source: DGEEC/MCE, 2000/01-2015/16.

Figure 1. Participation in higher education (ISCED5-8), Portugal, 2000/01-2015/16 (\%).

enrolled in social science; business and law; and in engineering, manufacturing and construction-fields with a broad range and that as a whole account for more than $50 \%$ of the students. Though this educational structure has remained stable in recent years, a pronounced decline has been noted in education and agriculture courses (sectors in which employment opportunities are also contracting), in contrast to a significant rise in the fields of health and welfare.

\subsection{Comparative Perspective}

In the preceding section, we presented a view of the Portuguese situation. Below, we identify some of the most striking features in the European context, along with the features that are most evident across the board.

One of these characteristics relates to the socio-demographic composition of those who attend higher education within the EU. In Europe, women are the ones with longer educational trajectories and higher qualifications. In fact, their histories in the system reflect greater "educational energy" (cf. Baudelot \& Establet, 1992), an aspect that is emphasised in various studies that cross gender with educational trajectories. 


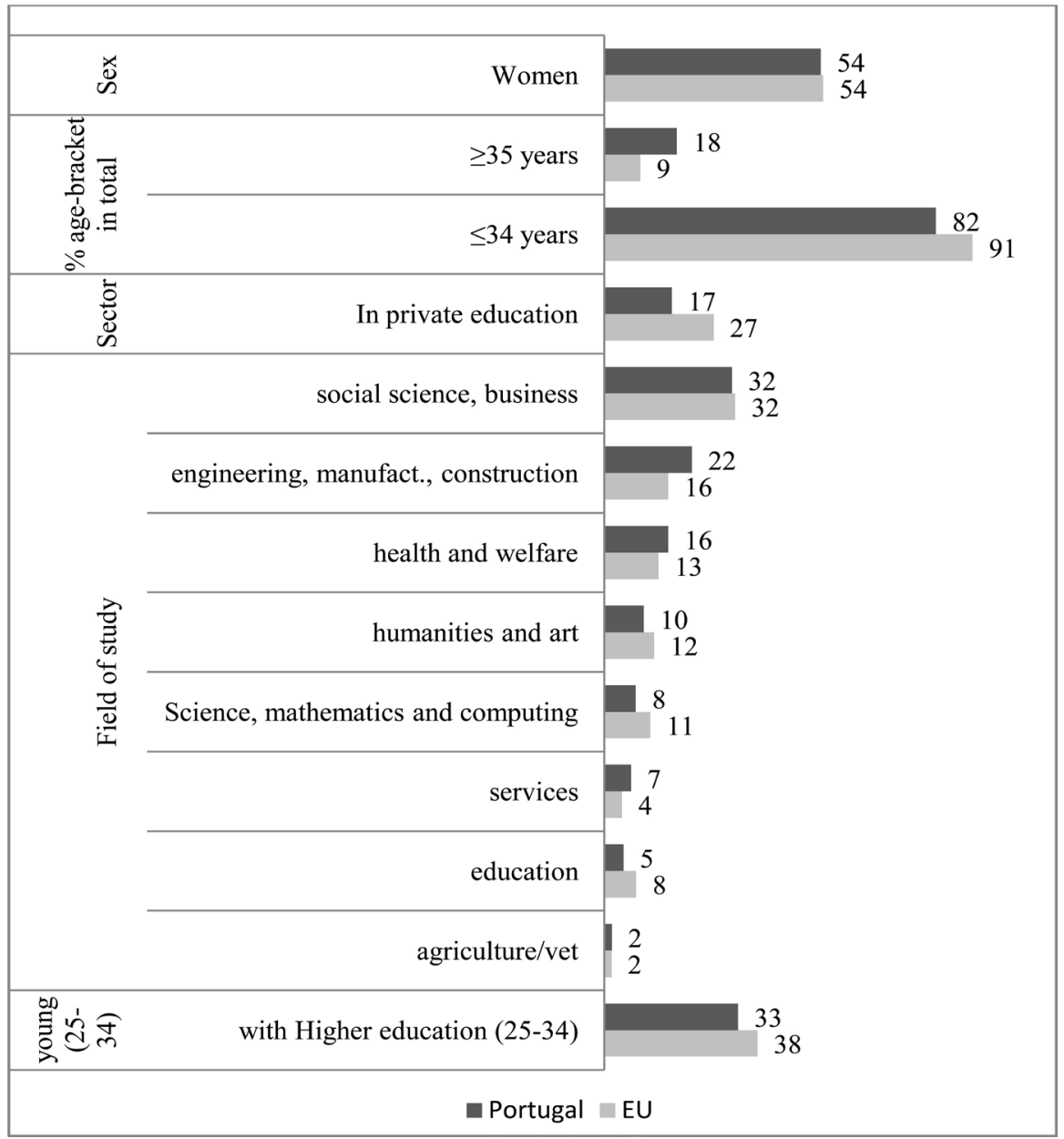

Note: The differences in the percentage of attends by field of study (Figure 1 and Figure 2) are explained because the reference year is different: PT. Students by age: 2012; young with higher education (25 - 34): 2015. Source: Eurostat, 2014 (consulted online December 2016).

Figure 2. Students enrolled in and graduating from higher education (ISCED5-8), Portugal and EU, 2014 (\%).

According to the data available for recent enrolments, Portuguese students are among the oldest in Europe. Nevertheless, the oldest age groups remain the least represented in higher education in the EU. According to available data on recent enrolments, Portuguese students are among the oldest in Europe. Even so, the oldest age groups remain the least represented in higher education in the EU. Although there is a European agenda that emphasizes the importance of lifelong learning, the fact is that older adults find it hard to return to education (Osborne, Rimmer, \& Houston, 2015).

Despite the convergence achieved in higher education systems, diversity in institutions is also highly conspicuous in the EU (cf. Martins, 2012). This institutional diversity is seen across Europe. Private education, for example, assumes very different proportions between groups of countries (cf. Martins, 2012). The discrepancies certainly affect institutional and perhaps even pedagogical and course models in the various countries. In the EU as a whole, private education reaches almost 30\%; in Portugal, this amount is lower (Altback \& Levy, 2005). 
With regard to the educational field, more than a third of the higher education students in the EU study in the fields of social science, business and law more than double the proportion of those in the second most popular fields (engineering, manufacturing and construction). However, the fields of social science bring together a very broad range of degrees, incorporating a large number of courses in almost all of the countries. On account of their specificity and the type of employability for which they are designed, agriculture and veterinary science, followed by services, are the least attractive fields for European students.

In the demographic perspective, we will give an analysis of the percentage of the population with a higher education in the age group in which, in most European countries, it is possible to have finished these studies (25 - 34 years of age). Almost $40 \%$ of the EU population in this age group are graduates. In Portugal, these percentages do not reach $35 \%$, indicating some delay in advanced schooling processes (Martins, 2012).

\section{Access to and Success in Higher Education: Theoretical Contributions}

A common issue in research centred on higher education relates to the discrepancies in the access opportunities and the probabilities of success. In fact, though there has been a progressive opening up of higher education, social inequalities are still reflected in student recruitment and participation (Bohonnek et al., 2010; Mauritti \& Martins, 2009; Orr, 2016; Scott, 2009; Shavit et al., 2007, to name just a few important publications). An analysis of a more structural type, such as proposed here, gives a great importance to variables related to social class and social backgrounds of students in higher education, either with respect to access or chances of success. This analytical dimension has been one of the main focuses of the sociology of education (at least since the consecrated work of J. Coleman and P. Bourdieu). Many authors discuss the importance of social class and cultural capital as comparative advantages that are reflected in different choices and possibilities for success in higher education (cf. Crozier, et al., 2008; Shavit et al., 2007; Werfhorst, Sullivan \& Cheung, 2003).

From the viewpoint of what has usually been recognised as the relative restrictiveness of this level of education, today's higher education systems are generally more open. In various countries, including Portugal, a twin pattern of social recruitment is starting to appear (Machado et al., 2003; Martins, Mauritti, \& Costa, 2005, 2007; Mauritti \& Martins, 2009). In other words, though strong dynamics of reproduction are still visible, it is certain that at the same time, social mobility processes can be observed in higher education (especially in Portugal). There is an expansion in the segment of students whose origins involve lower levels of education, and less skilled and less well-paid socio-professional positions.

In addition to social class inequalities, however, others-particularly those linked to gender/sex and ethnic group-have had an influence on access, on processes of learning and relating to educational institutions and, certainly, on performance, which includes the risk of discontinuation. These inequalities vary, 
marking the students' trajectories in very different ways, not only because of their diversity but also because of the various combinations that may result from them (Derouet, 2002; McNeal, 2011; Costa \& Lopes 2011).

Regarding a dimension of socio-demographic analysis, the inequalities revealed, for example, in the different intake according to gender still have a certain analytical importance. Some of the analyses proposed by the classical texts, whether those of Pierre Bourdieu or Raymond Boudon, "neglected the markedand sometimes paradoxical-differences that exist between the sexes" (Derouet, 2002: p. 11), differences that in the meantime various authors have tried to respond to from the point of view of their impact on educational careers (Baudelot \& Establet,1992; Deem, 1992; Duru-Bellat, Kieffer, \& Marry, 2001; Marry, 2000; Richardson \& Woodley, 2003). The differences between the sexes-significant despite everything-reflect a change in the demographics of the higher education population. In other words, we can see a transition from higher education systems that generally exclude women (evident in the academic qualifications of the older generations) to other educational systems that do not resist their entry on a broad scale (Martins, 2012). Another mark of openness in higher education relates to a greater age diversity of its students, giving expression to a greater presence of diversified academic and life trajectories.

The expansion of higher education, especially in developed countries, raises new research questions. A lot of the literature gives an account of social reproduction expressions in access to and success in higher education. At a time of expansion of higher education, these mechanisms do not disappear, but take on different contours that are reflected in other expressions of social hierarchies. The transformation of institutional and organizational models, now more flexible and open to different paths, and the introduction of policies on access by new segments of the population may be one of the most striking contributions made by the Bologna Process. This is particularly important in a country like Portugal, with a known educational deficit in relation to the rest of Europe.

Though authors such as José Madureira Pinto (2002) and Vincent Tinto $(1975,1997,2005)$ attach special importance to certain characteristics that are exogenous and exist from the start with respect to attendance at higher education, they still consider other characteristics to be of significance. Pinto stresses the specificity and internal differentiation of the Portuguese higher education system (reflected in the difference between university and polytechnic, public and private systems, and fields of study). He extends his analysis to the organisational and pedagogical questions of teaching institutions, including the relations between the various actors in these situations, and in particular the sociability between fellow students and friends. Tinto gives particular importance to student integration into institutional situations and to the effect of institutions on higher education careers and results. By the nature of the data processed within the framework of this article, it was very difficult to gauge the quality and intensity of these integration processes. These proposals always take individual char- 
acteristics into account with respect to social origins, personal attributes, and school careers prior to entry into higher education. These aspects will also be key dimensions in the work being presented in this article.

Though Tinto's research (Tinto, 1975, 2005) has marked many studies on the topic of higher education trajectories, in particular with regard to success, failure or discontinuation, other studies have revealed some of its limits (cf. Costa \& Lopes, 2011, particularly regarding a study in Portugal on the success and failure of students in higher education). Some of these studies confirm the importance of the component of student experiences and conditions in higher education institutions (considering aspects such as academic preparation, financing of studies, employment and support for families, friendship networks and sociability); or underline the organisational and institutional factors in these students' social and economic integration (e.g., institutional expectations or obligations, academic services, staff attitudes, teaching/learning, and assessment), allowing us to demonstrate institutional habitus (Thomas, 2003); or academic trajectories of various types by reference to success and discontinuation (some more according to the trend, others against it, with inflections or an indication of difficulties with integration or the reconciliation of the various spheres of life) (cf. Costa \& Lopes, 2011).

Certain recent studies report how, with the actual expansion of higher education public, some of the social inequalities registered have changed in extent and are more conspicuous in the ways that they combine with institutional differentiation in higher education-in particular, in the various forms of education and in relation to their social recognition and prestige-as seen in France (Lahire, 1997) but also in Germany (Schindler \& Reimer, 2011), the UK (Brennan \& Osborne, 2008) and Ireland (McCoy \& Smyth, 2011), among other examples.

\section{Methods and Data}

\subsection{Data-Gathering and Participants}

The analysis carried out in this article is, essentially, the result of an extensive and quantitative methodology. The empirical information used to develop an interpretation model for success in higher education, relying on logistic regression, was based on part of the empirical data from the Survey of Socioeconomic Conditions of Higher Education Students carried out throughout the country among Portuguese higher education students in 2006. Although not too recent, the importance of such data remains. This is justified for three reasons: a) there are no other national representative and reliable surveys more recent on this student population, with the same type of indicators (socioeconomic characterisation, institutional, and educational paths and academic success); b) this block of questions (on success and educational paths) is a specificity of the Portuguese questionnaire and of this round; and c) this survey was conducted in the context of expansion of the system and production policies aimed at opening access, namely those related with the Bologna Process implementation in Portugal.

The sample was stratified by legal status, type of institution, region, field of 
study and academic degree ${ }^{2}$. Special emphasis was placed on the sub-sample of first cycle students (undergraduates) ${ }^{3}$.

\subsection{Design and Data-Analysis}

Of the indicators included for this purpose, we note those relating in particular to educational pathways and academic success.

Table 1 presents the dimensions (blocks of explanatory variables) that form an analysis model that allows success in the Portuguese higher education system to be predicted (binary dependent variable) by means of a logistic regression ${ }^{4}$. The indicators making up these blocks are Socio-demographic characteristics (Block 1), Social origins (Block 2), Previous education (Block 3), Training and education institutions in HE (Block 4), Daily life indicators (Block 5). These analytical dimensions were based on the theoretical models developed by Vicent Tinto $(1975,1997)$ and Madureira Pinto $(2002)$ and the variables provided by the survey. These blocks and the hierarchical model were organized in accordance with these perspectives (especially Tinto, 1975, 1997). Individual, family (social background) and school attributes prior to entering higher education (Tinto, 1975, 1997), as shown in blocks 1, 2 and 3 respectively, were therefore considered first. Next, Block 4 covered the school system and its institutional and educational contexts, while Block 5 addressed what can be considered academic experiences and integration, which were measured only approximately on the basis of how students used their time. These last two blocks required greater adaptation of the Tinto model (1975 and 1997).

The dependent variable reflects, in simplified form, the state of having achieved academic success in higher education. It relates to the indicator based on the question directed to the students about whether they had failed any year in higher education. Though this indicator is not free of conceptual and operational problems, it identifies some of the most influential factors in successful higher education trajectories.

One of the most sensitive questions in this work was, precisely, the operationalisation of the indicator of educational success. This success, an example par excellence of a notion with many meanings, consists of a whole range of approaches whose processing and measurement are a complex matter, in particular when the available empirical information is taken into account. Philippe Perrenoud (2003) draws attention to this difficulty and distinguishes two main levels of educational success: one level of educational success is associated with the performance of the students, when they respond to the norms of educational excellence and progress in their courses; the other level of educational success concerns the success of an institution, with the best institutions being those that achieve the objectives of a situation of relative competition or those of an educa-

${ }^{2}$ We used face-to-face interviews (on paper).

${ }^{3}$ For the sub-sample used, $\mathrm{n}=2,828$. Its key reference was the model questionnaire provided by the Eurostudent Project, though it also included additional questions. In 2006, the sample population included 367,312 students (2006)

${ }^{4}$ The multicollinearity was also checked and all the tolerance values are up to 0.01 (Hair et al, 2010). 
Table 1. Success in higher education: the application of logistic regression.

\begin{tabular}{|c|c|}
\hline $\begin{array}{l}\text { Dimensions of analysis } \\
\text { (Blocks of variables) }\end{array}$ & Independent variables \\
\hline $\begin{array}{c}\text { Socio-demographic } \\
\text { characterization (Block 1) }\end{array}$ & $\begin{array}{l}\text { Sex: Male | Female } \\
\text { Age }\end{array}$ \\
\hline Social origins (Block 2) & $\begin{array}{l}\text { Socio-occupational categories (social classes) } \\
\text { entrepreneurs and executives } \\
\text { professionals and managers } \\
\text { self-employed } \\
\text { routine employees } \\
\text { industrial workers } \\
\text { multi-active employees } \\
\text { Years of schooling of father } \\
\text { Years of schooling of mother }\end{array}$ \\
\hline $\begin{array}{l}\text { Previous education } \\
\text { (Block } 3)\end{array}$ & $\begin{array}{l}\text { Earlier failure (year repeated): Yes | No } \\
\text { Route of access to higher education } \\
\text { general course } \\
\text { technological course } \\
\text { vocational course } \\
\text { "second-chance" education } \\
\text { Other } \\
\text { Sector in secondary education: Public | Private (or cooperative) }\end{array}$ \\
\hline $\begin{array}{l}\text { Characterization of training } \\
\text { and educational institutions } \\
\text { in HE (Block 4) }\end{array}$ & $\begin{array}{l}\text { Sector of educational institution: Public | Private (or cooperative) } \\
\text { Education subsystem: University | Polytechnic } \\
\text { Field of study } \\
\text { Education } \\
\text { humanities and art social science, business and law } \\
\text { science, mathematics, computing } \\
\text { engineering, manufacturing, construction } \\
\text { agriculture and Veterinary } \\
\text { health and welfare } \\
\text { Services }\end{array}$ \\
\hline $\begin{array}{l}\text { Daily life indicators } \\
\text { (Block 5) }\end{array}$ & $\begin{array}{l}\text { Average number of hours per week in class activities } \\
\text { Average number of hours per week studying } \\
\text { Average number of hours per week working }\end{array}$ \\
\hline
\end{tabular}

tional system taken as a whole. Even so, the two levels of success mentioned are clearly related. After this, we focus more closely on the first level, with particular attention being given to the performance of higher education students within the framework of the Survey of the Socio-Economic Conditions of Higher Education 


\section{Students.}

The indicators for higher education students' success or failure, which were included when the survey was carried out in 2006, relate to the students' own declarations of the presence or absence of failure in their whole educational career, with a distinction being made between the various education cycles. In the analysis, precedence is given to the occurrence of these indicators in higher education.

From our reading of the results for educational success and failure in the first (undergraduate) cycle of higher education, we can state that under the conceptual and operational conditions at our disposal, $78.2 \%$ of the respondents declared that they had never failed at this level, which constitutes a situation of educational success (Table 2). It is important to mention that at the time of the survey, the students had not yet finished their courses and so could still fail at that stage of their academic career. Accordingly, that percentage could certainly be underestimated. Even so, the percentage represents the first measurement of the object in question.

The interpretation of these percentages involves certain indefiniteness. Not only are the students' own perceptions of the concept of "educational failure" taken into account, but the concept is also marked by a myriad of evaluations that punctuate and reorient the educational trajectory. In addition, there is no broad and established consensus regarding what exactly is being referred to (an aspect stressed by Perrenoud, 2003). Furthermore, the concept of educational success has various gradations and is a nuanced concept, par excellence, at various levels. These gradations are not recognised here given the difficulty in obtaining highly specific information on the classification dimensions of this success.

Other formulations have been based on the prolongation of higher education studies (measured in years of delay), commonly registered in the statistics as educational failure. However, these "delays" may often be the result of changes of direction in education (transfers between courses or institutions) or the students' participation in the labour market, which may complicate the pursuit of their studies within the time limit prescribed by their formal study plans, though they do not necessarily indicate negative results (cf. CHEPS and NIFU, 2015).

As stated, the formulation accepted for this research may not be problem-free. However, when combined with different variables and taken as a starting point for highly valuable multivariate analyses to ascertain the complexity and

Table 2. Indicator of educational success among students in the first higher education cycle (\%).

\begin{tabular}{cc}
\hline Higher education & $\%$ \\
\hline No years failed & 78.2 \\
With failure & 21.8 \\
Total $(\mathrm{n}=2824)$ & 100.0 \\
\hline
\end{tabular}

Source: CIES-IUL, 2006. 
multi-dimensionality involved in comprehending success in higher education trajectories, this formulation may reveal important trends and the meanings of analytical relationships.

\section{Success in Higher Education: An Interpretative Model}

To assess the relative importance of a set of dimensions in explaining success in higher education, a model was defined and tested using Binary Logistic Regression. A hierarchical regression was used because the model includes different blocks of explanatory dimensions: a) socio-demographic indicators (individual attributes), b) indicators characterising social origins, c) indicators relating to earlier educational careers, d) indicators characterising schooling and educational institutions, and e) indicators characterising daily life.

The first block of predictive variables (Block 1) concerns demographic characteristics, which include sex and age. One of the striking results of this first model is that both age and sex are significantly related to success in tertiary education $\left(\chi^{2}(2)=152.830, p<0.001\right)$. These effects demonstrate that the possibility of success in higher education is higher among girls and younger students. Thus, the model presented here, still viewed from a partial perspective, immediately reveals a demographic pattern associated with successful higher education students.

When the second block is added, this time relating to social origins (Table 3), the relationships noted above with demographic variables are maintained. However, this new block, which includes social class and parental years of schooling, does not significantly affect the explanation of the success $\left(\chi^{2}(7)=\right.$ 7.516, $p>0.05)$. That is, the social inequalities at the starting point, still highly evident in access to Portuguese higher education (Martins et al., 2007; Mauritti \& Martins, 2009), do not have a significant effect on the possibility of being successful for those who have already entered higher education. As is already known, this may be a subsidiary effect of highly selected trajectories in earlier educational stages (and, therefore, those who reach this level have sufficient merit for the social conditions at the starting point to interfere less) (cf. Breen \& Jonsson, 2005; Schlicht et al., 2010), or it may be because the dependent variable used here does not allow us to capture different gradations of success in an analysis of the main contingent of the first (undergraduate) cycle of higher education. Another observation that may also explain the weakening of the variable on social origins in this model involves the importance of the contexts and types of institution and education, which are always marked by social mechanisms and hierarchies-for the Portuguese situation, cf. Martins et al. (2007); for other European cases, see also Boliver (2011), Brennan \& Osborne (2008), Shindler \& Reimer (2011). Additionally, the visibility of these effects may have been transferred to the subsequent higher education levels, not only with regard to access but also the probability of success.

The third block covers educational careers prior to admission to higher education and has a significant effect $\left(\chi^{2}(6)=17.298, p<0.01\right)$. It is important to 
note here that the students who followed technological courses at the secondary level have a lower probability of success at the higher education level (odds ratio $=0.687, p<0.05)$ compared to general course students. For many secondary school careers, a technical and occupational education may have already been a response to combat the failure that had occurred there. The weight of the type of school trajectories first determines access, visible in most European countries (Griga \& Orr, 2010), but also leaves some marks on success in higher education, as seen in this study in relation to the Portuguese reality.

Table 3. (a) Success in higher education: Determining factors (Hierarchical Binary Logistic Regression); (b) success in higher education: determining factors (cont.).

(a)

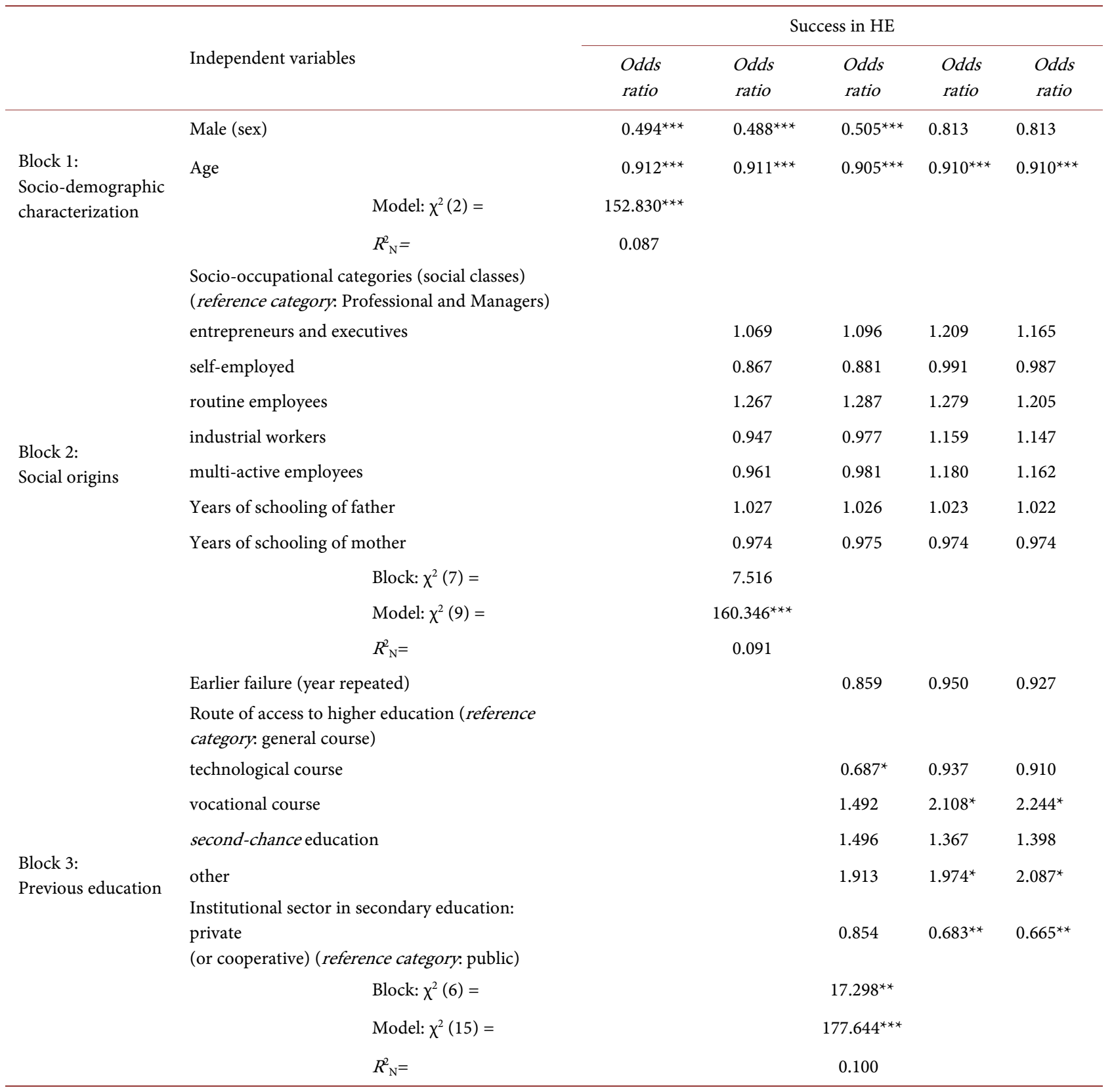

${ }^{*} p<0.05{ }^{* *} p<0.01{ }^{* * *} p<0.001$ 
(b)

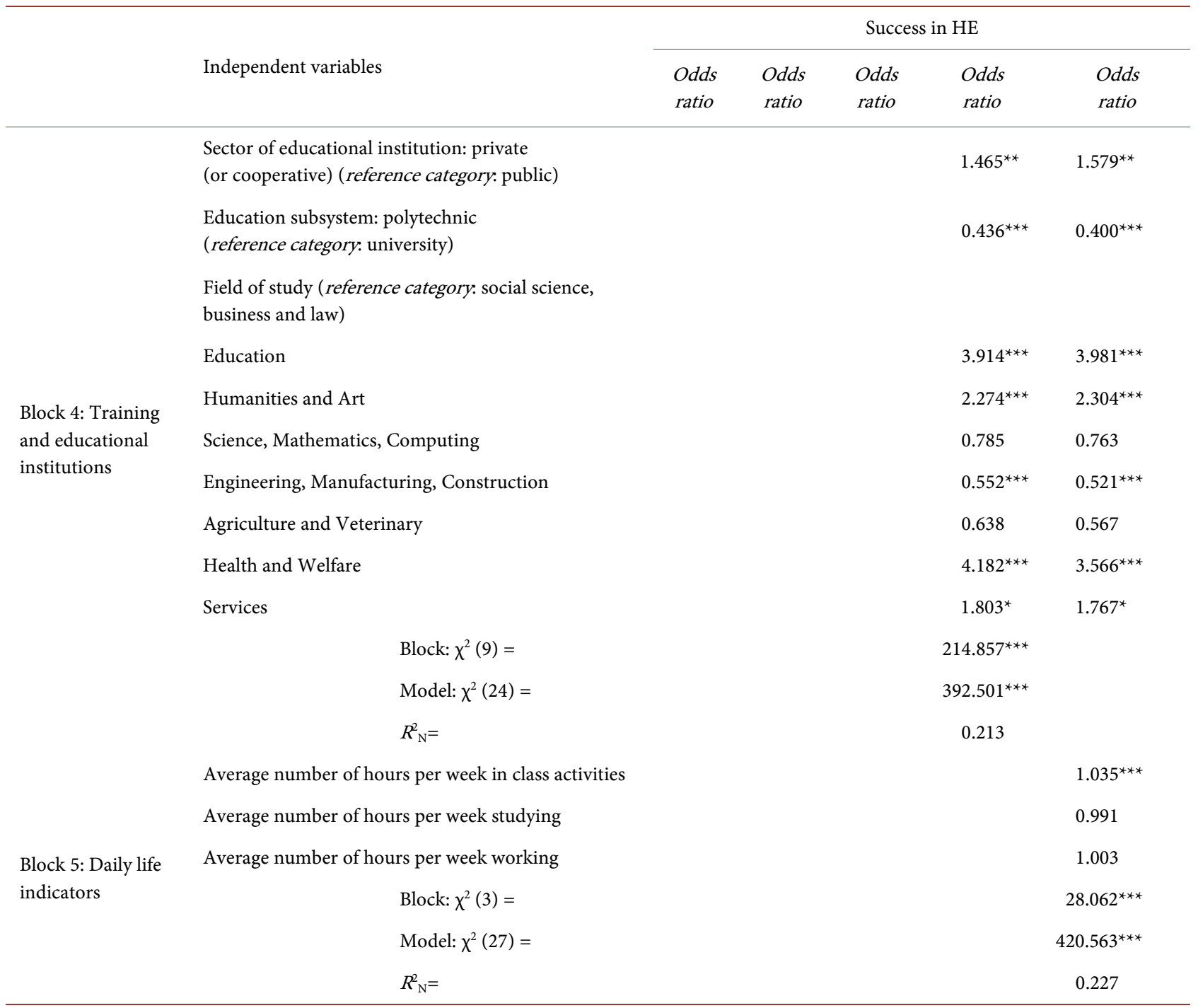

${ }^{*} p<0.05,{ }^{* *} p<0.01,{ }^{* * *} p<0.001$.

The indicators characterising education and educational institutions (Block 4) are undoubtedly those that have the greatest effect in explaining higher education success $\left(\chi^{2}(3)=214.857, p<0.001\right)$. In relation to the subsystems, studying at a polytechnic reveals a greater probability of failure at this level (odds ratio $=$ $0.436, p<0.001$ ), whereas following university studies increases the possibility of success as operationalised here.

The fields of study provide an additional perspective to the research problem in question. In fact, detailed analysis of the importance of this variable, as a factor of success or failure in higher education, allows us to note four situations when the different study fields are compared with the category of reference, Social Science, Business and Law:

a) The first relates to Health and Welfare students, who generally experience less educational failure (odds ratio $=4.182, p<0.001$ ). Moreover, as various studies have indicated, those enrolled in this field are more likely to be female 
and also reflect strong social reproduction (at the socio-professional and qualification levels) (Bourdieu \& Passeron, 1970). On this subject, see the case of Portuguese students in health courses, e.g., Machado et al. (2003);

b) Education students have the highest levels of failure in their schooling prior to admission to higher education (according to their own questionnaire responses), though, at this level, they follow those mentioned above in presenting the progressions most protected from course repetition (odds ratio $=$ 3.914, $p<0.001$ ). This segment, which is also more likely to be female, though its social recruitment is the broadest, has managed somewhat to turn earlier school careers with achievement problems into successful ones in higher education;

c) Students in Humanities and Art and Services also tend to be more successful in higher education (respectively, odds ratio $=2.274, p<0.001$ and odds ratio $=1.803, p<0.05)$ when compared to Social Science, Business and Law students;

d) Engineering students, mainly male, invert the educational performance trend among those above. Although the rates of success in primary and secondary schooling are close to those of the whole higher education population, at this level they present the lowest probability of success (odds ratio $=0.552, p<$ 0.001 ) and the highest possibility of repetition, compared to students from the fields of Social Science, Business and Law.

In this comparison, the distances between the engineering and education students' records reveal not only different assessment cultures and instruments (with, to a greater or lesser extent, facilitating appropriations) but also different educational and pedagogical attitudes and objectives (in the learning framework and vocational motivation), as well as varying types of reception by the institutions (when we also take the differences between educational sectors and subsectors into account).

The educational sector also has a significant effect (odds ratio $=1.465, p<$ 0.01 ); it can be seen that in comparison to their counterparts in the public network, private and cooperative education students have a higher probability of completing their education without failure, with such episodes figuring to a lesser degree in their academic careers.

It is also important to add that the introduction of Block 4-a set of variables describing the factors related to integration into and the experience of education, in addition to specificities of the educational system-gains importance with regard to the possibility of repetition in higher education (a variable included in Block 3). This model strengthens the perspective that for those who studied in that sector, the possibility of failure in higher education tends to rise (odds ratio $=0.665, p<0.01$ ), i.e., it does not represent an advantage in the educational careers of the student population enrolled.

To complete the model explaining success in higher education, a final block is inserted, relating to the students' daily lives or, more exactly, the average time spent in contact hours, study and work. Though the weight of this last block is 
not very great, it still has a significant effect $\left(\chi^{2}(3)=28.062, p<0.001\right)$. With regard to the contribution of the indicators, a salient feature is that the students who spend most hours, on average, in contact activities form the segment with the highest likelihood of success (odds ratio $=1.035, p<0.001$ ).

To sum up, the variables with the most influence on situations of higher education success are-according to their effect size-characteristics of the educational institution, type of education, field of education, age (reflecting individual life cycles), organisation of the daily periods more or less dedicated to contact activities, and schooling conditions at the starting point, in particular access routes and state-sector secondary studies.

\section{Discussion and Conclusion}

This model, oriented towards the successful paths of students, combines very profitably with the recognition of the higher education system (students enrolled and graduates) and its main policy orientations. These two approaches are not only reconcilable but also highly productive in the reciprocal gains of greater analytical force. This triangulation provides us with a better knowledge of the processes and results involved in some of the political, institutional and social changes in higher education.

The perspective of Portuguese higher education adopted here can also be useful in analyses in countries where its expansion is also recent. Policies in Portugal have focused mainly on social enlargement and increased participation and less on success and national regulation (CHEPS and NIFU, 2015). These circumstances can be seen in a number of other countries, especially in Eastern Europe. The analytical model presented here is designed as a basis for reflection on success in higher education not only in Portugal, but also in countries with similar participation and graduation dynamics and the same kind of political orientations.

Higher education has undoubtedly been the object of political intervention, though its effects-in particular in the social and demographic structure and in the type of institutional relationship that they establish with the educational organisations in which they study or have studied-seem to be moderate and fairly slow. However, some of the most important dynamics at the European level are also recognised in the Portuguese system. In this regard, through a reading of the statistical data presented in the first part of this article, which covers about a decade and a half, we can observe certain stability. However, we can also recognise the effect of policies on some transformations of the profile of these students in the demographic characterisation, as well as in the institutional and educational analysis. This provides a number of assurances with regard to how far the use of the data from the Socio-economic Survey of Higher Education Students is up to date and relevant. The logistic regression model undertaken, using these data as its base, underlines precisely the institutional and educational dimensions as differentiated contexts with significance in distinct academic results. However, we would make a last note regarding the conception of academic 
success used, which principally expresses the main trends in educational trajectories, without offering the possibility of a detailed reading of various levels and echelons of academic success. The effect is stronger when it is known that the various educational institutions and fields develop their own methods of recruiting and assessing their students, with evident differences in their criteria, values and outlook. If the pressure of the Bologna Process in the harmonisation and standardisation of student assessment processes is taken into account, such a task seems too difficult (Sin \& Manatos, 2013), given not only the institutional diversity but also the greater diversity among students. In addition to this complexity, these institutional and educational contexts are not immune to social mechanisms and hierarchies that certainly influence access (as confirmed by earlier studies already mentioned) as well as the performance of their students. In this way, although this model is beneficial on account of the type of results it achieves and the interpretations it makes possible, it still raises many questions and uncertainties-in brief, it still raises questions about new problems that, if tested more thoroughly, could give rise to further research. However, after considering a set of policies aimed at opening up higher education, this model offers insight regarding the formulation of policies that promote paths of academic success.

In reality, Portugal currently faces new circumstances with regard to higher education. After a clear cycle of opening up, the Portuguese education system met some setbacks in recent years, particularly concerning the number of students enrolled in higher education (Rodrigues \& Heitor, 2015). It is a moment to ponder the policies that contribute to access and success in higher education. This preoccupation with success and completion in higher education was also intensified in the guidelines and modes of governance at a European level (CHEPS and NIFU, 2015). There are some points that warrant more research and dialogue with policy makers and to which our research has only provided some clues.

Recognising modes of access to higher education by identifying the nature of the main obstacles to sustainability among those entering higher education.

- Interpreting how different previous paths of education guided access and success in higher education.

- Concerning this, some questions can be asked. How have different study areas hosted and designed different paths of success?

- How can different institutions, positioned in different subsystems of the education provisioning network, accommodate increasingly diversified students while implementing equivalent modes of promotion and recognition of success?

- Despite the fact that differences in social origins seem to weigh more on access than on success in higher education, how are social and economic dimensions present in higher education and how do they influence the guidelines and decisions made by students when undertaking their courses?

- Is it possible that from the impacts of a period of relative productivity of po- 
litical measures that were largely framed by the implementation of the Bologna Process and mainly focused on access and flexibility of attendance, a new generation of policies taking into account the promotion of success with a public that is increasingly diversified can be designed?

These exploratory questions may be good pointers for further research and policy questions about new directions for higher education in Portugal, taking account of the requirements of the European Area for Higher Education.

\section{References}

Altback, P., \& Levy, D. (2005). Private Higher Education: Global Revolution. Rotterdam: Sense Publishers.

Baudelot, C., \& Establet, R. (1992). Allez les filles! Paris: Máspero.

Bohonnek, A., Camilleri, A. F., Griga, D., Mühleck, K., Miklavič, K., \& Orr, D. (2010). Evolving Diversity: An Overview of Equitable Access to Higher Education in Europe (136 p). Brussels: The EQUNET Consortium, European Commission.

Boliver, V. (2011). Expansion, Differentiation, and the Persistence of Social Class Inequalities in British Higher Education. Higher Education, 61, 229-242.

https://doi.org/10.1007/s10734-010-9374-y

Bologna Process Working Group (2007). Key Issues for the European Higher Education Area-Social Dimension and Mobility. http://www.regeringen.se/49b72f/contentassets/f7fbd3c20af0477495cb35c87768fd82/ke y-issues-for-the-european-higher-education-area---social-dimension-and-mobility

Bourdieu, P., \& Passeron, J. (1970). La reproduction: Elements pour une theorie du systeme d'enseignement. Paris: Minuit.

Breen, R., \& Jonsson, J. O. (2005). Inequality of Opportunity in Comparative Perspective: Recent Research on Educational Attainment and Social Mobility. Annual Review of Sociology, 31, 223-243. https://doi.org/10.1146/annurev.soc.31.041304.122232

Brennan, J., \& Osborne, M. (2008). Higher Education's Many Diversities: of Students, Institutions and Experiences, and Outcomes? Research Papers in Education, 23, 179-190. https://doi.org/10.1080/02671520802048711

CHEPS and NIFU (2015). Dropout and Completion in Higher Education in Europe. Main Report, Luxembourg: Publications Office of the European Union.

Costa, A. F., \& Lopes, J. T. (2011). The Diverse Pathways of Higher Education Students: A Sociological Analysis on Inequality, Context and Agency. Portuguese Journal of Social Science, 10, 43-58. https://doi.org/10.1386/pjss.10.1.43_1

Crozier, G., Reay, D., Clayton, J., Colliander, L., \& Grinstead, J. (2008). Different Strokes for Different Folks: Diverse Students in Diverse Institutions-Experiences of Higher Education. Research Papers in Education, 23, 167-177. https://doi.org/10.1080/02671520802048703

Deem, R. (1992). Schooling and Gender: The Cycle of Discrimination. In J. Lynch, C. Modgil, \& S. Modgil, (Orgs.), Cultural Diversity on the Schools, Vol. 3: Equity or EXcellence? Education and Cultural Reproduction (pp. 81-97). London: The Falmer Press.

Derouet, J.-L. (2002). A sociologia das desigualdades em educação posta à prova pela segunda explosão escolar: Deslocamento dos questionamentos e reinício da crítica. Revista Brasileira de Educação, 2, 5-16. https://doi.org/10.1590/S1413-24782002000300002

Duru-Bellat, M., Kieffer, A., \& Marry, C. (2001). La dynamique des scolarités des filles: le double handicap questionné. Revue Française de Sociologie, 42, 251-281. 
https://doi.org/10.2307/3322966

Griga, D., \& Orr, D. (2010). Chapter 4: Entry into Higher Education. In A. Bohonnek, A. F. Camilleri, D. Griga, K. Mühleck, K. Miklavič, \& D. Orr (Eds.), Evolving Diversity: An Overview of Equitable Access to HE in Europe (pp. 29-43). Brussels: The EQUNET Consortium, European Commission.

Hair, J., Black, W., Babin, B., \& Anderson, R. (2010). Cluster Analysis. In: J. Hair, W. Black, \& B. Babin (Eds.), Multivariate Data Analysis: A Global Perspective (7th ed., pp. 477-536), New York: Pearson Prentice Hall.

Lahire, B. (1997). Les manières d'étudier. Paris: OVE.

Machado, F. L., Costa, A. F., Mauritti, R., Martins, S. C., Casanova, J. L. and Almeida, J. F. (2003). Classes sociais e estudantes universitários. Revista Crítica de Ciências Sociais, 66, 45-80. https://doi.org/10.4000/rccs.1140

Marry, C. (2000). Filles et garçons à l'école. In A. V. Zanten (Ed.), L'École l'état des savoirs (pp. 283-292). Paris: Éditions la Découverte.

Martins, S. C. (2012). Escolas e estudantes da Europa: Estruturas, recursos e políticas de educação. Lisbon: Editora Mundos Sociais.

Martins, S. C. (2015). A abertura do ensino superior à diversidade de públicos: Políticas e orientações. In M. L. Rodrigues, \& M. Heitor (Eds.), 40 Anos de políticas de ciência e de ensino superior (pp. 735-756). Lisbon: Almedina.

Martins, S. C., Mauritti, R., \& Costa, A. F. (2005). Social and Economic Conditions of Students in Portugal. Lisbon: DGES/MCTES.

Martins, S. C., Mauritti, R., \& Costa, A. F. (2007). Higher Education Students: Survey of Socio-Economic Conditions, 2007. Lisbon: DGES/MCTES.

Mauritti, R., \& Martins, S. C. (2009). Higher Education Students: Contexts and Social Origins. In A. F. Costa, F. L. Machado, \& P. Ávila (Eds.), Knowledge and Society, Vol. 2: Portugal in the European Context (pp. 81-97). Lisbon: Celta Editora.

McCoy, S., \& Smyth, E. (2011). Higher Education Expansion and Differentiation in the Republic of Ireland. Higher Education, 61, 243-260. https://doi.org/10.1007/s10734-010-9375-x

McNeal Jr., R. (2011). Labour Market Effects on Dropping out of High School: Variation by Gender, Race, and Employment Status. Youth Society, 43, 305-332. https://doi.org/10.1177/0044118X10363776

Orr, D. (2016). Monitoring Cross-Country Performance in Equality of Access and Affordability of Tertiary Education-A Review of Options. UNESCO, Global Education Monotoring Report.

Osborne, M., Rimmer, R., \& Houston, M. (2015). Adult Access to Higher Education: An International Overview. In J. Yang, C. Schneller, \& S. Roche (Eds.), The Role of Higher Education in Promoting Lifelong Learning (pp. 17-39). Hamburg: UNESCO Institute for Lifelong Learning.

Perrenoud, P. (2003). Sucesso na escola: Só o currículo, nada mais que o currículo! Cadernos de Pesquisa, 119, 7-26. https://doi.org/10.1590/s0100-15742003000200001

Pinto, J. M. (2002). Factores de sucesso/insucesso. In CNE (Org.), Sucesso e Insucesso Escolar no Ensino Superior Português (pp. 121-141). Lisbon: CNE.

Rauhvargers, A., Deane, C., \& Pauwels, W. (2009). Bologna Process Stocktaking Report 2009.

http://media.ehea.info/file/2009_Leuven_Louvain-la-Neuve/94/7/Stocktaking_report_2 009_FINAL_594947.pdf

Richardson, J., \& Woodley, A. (2003). Another Look at the Role of Age, Gender and Subject as Predictors of Academic Attainment in Higher Education. Studies in Higher 
Education, 28, 475-493. https://doi.org/10.1080/0307507032000122305

Rodrigues, M. L., Heitor, M. et al. (2015). 40 Anos de políticas de ciência e de ensino superior. Lisbon: Almedina.

Schindler, S., \& Reimer, D. (2011). Differentiation and Social Selectivity in German Higher Education. Higher Education, 61, 261-275.

https://doi.org/10.1007/s10734-010-9376-9

Schlicht, R., Stadelmann-Steffen, I., \& Freitag. M. (2010). Educational Inequality in the EU: The Effectiveness of the National Education Policy. European Union Politics, 11, 29-59. https://doi.org/10.1177/1465116509346387

Scott, P. (2009). Access in Higher Education in Europe and North America: Trends and Developments.

Shavit, Y., Arum, R., \& Gamoran, A. (2007). Stratification in Higher Education: A Comparative Study. Stanford, CA: Stanford University Press.

Sin, C., \& Manatos, M. (2013). Student Assessment in Portugal: Academic Practice and Bologna. Policy Higher Education Policy, 27, 323-340.

https://doi.org/10.1057/hep.2013.27

Thomas, L. (2002). Student Retention in Higher Education: The Role of Institutional Habitus. Journal of Educational Policy, 17, 423-442.

https://doi.org/10.1080/02680930210140257

Tinto, V. (1975). Dropout from Higher Education: A Theoretical Synthesis of Recent Research. Review of Educational Research, 45, 89-125.

http://www.jstor.org/stable/1170024

https://doi.org/10.3102/00346543045001089

Tinto, V. (1997). Classrooms as Communities: Exploring the Educational Character of Student Persistence. The Journal of Higher Education, 68, 599-623.

https://doi.org/10.2307/2959965

Tinto, V. (2006). Enhancing Student Persistence: Lessons Learned in the United States. Análise Psicológica, 1, 7-13.

Van De Werfhorst, H., Sullivan, A., \& Cheung, S. (2003). Social Class, Ability and Choice of Subject in Secondary and Tertiary Education in Britain. British Educational Research Journal, 29, 41-62. http://www.jstor.org/stable/1501538

https://doi.org/10.1080/0141192032000057366 
Submit or recommend next manuscript to SCIRP and we will provide best service for you:

Accepting pre-submission inquiries through Email, Facebook, LinkedIn, Twitter, etc. A wide selection of journals (inclusive of 9 subjects, more than 200 journals)

Providing 24-hour high-quality service

User-friendly online submission system

Fair and swift peer-review system

Efficient typesetting and proofreading procedure

Display of the result of downloads and visits, as well as the number of cited articles Maximum dissemination of your research work

Submit your manuscript at: http://papersubmission.scirp.org/

Or contact ce@scirp.org 